\title{
DESAIN VEGETASI BERNILAI KONSERVASI DAN EKONOMI PADA KAWASAN PENYANGGA SISTEM TATA AIR DAS BOLANGO (Designing of Vegetation which Conservation and Economic Values in the Buffer Area of Water System at the Bolango Watershed)
}

\author{
Danang Wahyu Purnomoo,*, Apong Sandrawati², Joko Ridho Witono', \\ Izu Andry Fijridiyanto ${ }^{1}$, Dwi Setiyanti ${ }^{1}$ dan Dina Safarinanugraha ${ }^{1}$ \\ ${ }^{1}$ Pusat Konservasi Tumbuhan Kebun Raya, Lembaga Ilmu Pengetahuan Indonesia, \\ Jl. Ir. H. Juanda 13 PO Box 309, Bogor, Jawa Barat 16003. \\ ${ }^{2}$ Fakultas Pertanian, Universitas Padjajaran, Jl. Raya Bandung Sumedang Km.21, \\ Jatinangor, Jawa Barat 45363.
}

*Penulis korespondensi. Tel/fax. 0251 8322187. Email: dnabdz@yahoo.com.

Diterima: 29 Januari 2015

Disetujui: 29 September 2015

\begin{abstract}
Abstrak
Perencanaan pembangunan arboretum di DAS Bolango dengan konsep konservasi dan ekonomi perlu dilakukan karena DAS ini memiliki peranan yang penting dalam kehidupan masyarakat sekitar. Tujuan penelitian ini adalah memberikan rekomendasi tentang komposisi dan struktur vegetasi penyusun hutan pada kawasan arboretum sebagai pemelihara mata air Sungai Bolango. Penelitian dimulai dengan mengidentifikasi sumber mata air, tanah, dan kondisi vegetasi eksisting. Metode wawancara kepada masyarakat setempat dilakukan untuk mendukung data etnobotani. Kajian lahan dilakukan antara lain tata guna, kelas kemampuan, konsep pengelolaan, kesesuaian lahan, dan penentuan vegetasinya. Hasil identifikasi sumber mata air menunjukkan bahwa terdapat 3 lokasi yang potensial dibangun arboretum, yaitu Desa Meranti Kecamatan Tapa Kabupaten Bone Bolango, Desa Dulamayo Selatan Kecamatan Telaga Kabupaten Gorontalo, dan Desa Mongiilo Kecamatan Bolango Ulu Kabupaten Bone Bolango. Berdasarkan data kualitas tanah, ketiga lokasi memiliki media perakaran yang cukup baik untuk tanaman budi daya. Secara umum, semua jenis tanaman budi daya sesuai untuk ditanam di ketiga lokasi arboretum. Perlu dilakukan pembuatan teras dan penerapan pola tanam konservasi yang mengaplikasikan tanaman penutup tanah (cover crop), tanaman budi daya, dan pohon penyusun hutan. Selain itu, perlu pemberian pupuk organik berupa kompos dan pupuk kandang.
\end{abstract}

Kata kunci:. arboretum, daerah aliran sungai, kesesuaian lahan, komposisi vegetasi, struktur vegetasi

\begin{abstract}
Arboretum development planning in Bolango Watershed using concept of conservation and economy is conducted because the watershed has an important role in people's lives around. This study aims to provide recommendations about composition and structure of forest vegetation in the arboretum area for conserving of Bolango River's water springs. The study began by identifying the source of the springs, soil, and the existing vegetation. Interview to local communities was conducted to support the data of ethnobotany. Land observation was studied among other land use, class capabilities, management concepts, land suitability, and vegetation selection. The results of the identification of water sources indicated that there were three potential sites built arboretum, i.e Meranti Village Tapa District of Bone Bolango Regency, Dulamayo Selatan Village, Telaga District of Gorontalo Regency, and Mongiilo Village Bolango Ulu District of Bone Bolango Regency. Based on the data of the soil quality, the third location had a pretty good rooting medium for plant cultivation. Generally, all of plant cultivation were suitable to planted in the third location of arboretum. There were important to built terraces and applicate a model of conservation plants using cover crops, cultivation plants, and trees. In addition, it should be applicated organic fertilizer such as compost and manure.
\end{abstract}

Keywords: arboretum, watershed, land suitability, vegetation composition, vegetation structure

\section{PENDAHULUAN}

Keseimbangan sumber daya air dalam suatu Daerah Aliran Sungai (DAS) dapat tercapai bila keseimbangan antara ekosistem daratan dan ekosistem akuatik dapat terpelihara dengan baik. Komposisi dan struktur vegetasi memegang peran penting dalam menanggulangi proses-proses hidrologi pada suatu kawasan. Proses-proses hidrologi penting itu meliputi penyiraman permukaan area resapan (rainfall interception), peresapan air hujan ke dalam pori-pori tanah (infiltration), pengisian secara tidak teratur genangan (depression storage), dan limpasan air 
hujan yang membentuk kedalaman aliran (stormwater runoff) (Anonim, 2007). Perubahan tutupan vegetasi secara langsung akan mempengaruhi aliran air pada suatu ekosistem DAS. Bahkan untuk jangka panjang, jika pengelolaan hutan mampu mengendalikan perubahan iklim melalui pengaturan presipitasi (Laird dkk., 2011).

Masalah pokok dalam pengelolaan sumber daya air sangat kompleks, di antaranya: fluktuasi debit pada musim kemarau dan musim hujan, kerusakan lahan di daerah tangkapan air, erosi dan sedimentasi, kecenderungan penggunaan air yang belum efisien, pertambahan limbah yang masuk sungai, dan pengurangan kemampuan pemulihan kembali sungai (Irianto dan Rejekiningrum, 2008). Jika masalah-masalah ini tidak segera ditangani, maka ketersediaan air dengan kualitas yang memadai di semua tempat dan sepanjang waktu akan semakin sulit dan mahal.

DAS Bolango merupakan salah satu dari 3 (tiga) DAS terbesar yang ada di wilayah Sungai Limboto Bolango Bone. DAS Bolango memiliki luas 52.778 ha dengan 4 cabang anak sungai besar yaitu Sungai Pupalo, Sungai Bongo, Sungai Mongiilo dan Sungai Palanggua yang terletak di Kabupaten Bone Bolango, Kabupaten Gorontalo dan Kota Gorontalo. DAS ini memiliki peranan yang penting dalam kehidupan masyarakat yang saat ini telah mengalami degradasi dan kerusakan lingkungan (Tresnadi, 2008). Kondisi masyarakat sekitar DAS Bolango masih berada di bawah garis kemiskinan, dimana 52,1-64,2\% penduduk masuk penerima raskin (Anonim, 2011 ${ }^{\mathrm{a}}$ ). Sektor penghasilan masyarakat terbesar adalah sektor pertanian dan perkebunan (Anonim, 2011 b).

Berdasarkan kondisi tersebut maka diperlukan pembangunan arboretum, sebuah konsep kawasan perlindungan mata air yang dipadukan dengan aspek pendidikan dan penelitian, serta partisipasi aktif masyarakat sekitar. Salah satu aspek penting dalam pembangunan arboretum ini adalah pengelolaan vegetasi penyusun hutan yang memiliki fungsi perlindungan terhadap tanah dan air, serta bernilai ekonomi bagi kesejahteraan masyarakat sekitar. Tujuan penelitian ini adalah memberikan rekomendasi jenis-jenis penyusun hutan pada kawasan arboretum sebagai pemelihara mata air Sungai Bolango. Pengaturan komposisi dan struktur vegetasi yang tepat diharapkan akan mengatur kelestarian proses-proses hidrologi kawasan di sekitar mata air Sungai Bolango.

\section{METODE PENELITIAN}

\section{Waktu dan Lokasi}

Penelitian ini dilaksanakan pada tanggal 22 April - 3 Mei 2012. Penelitian ini dilakukan di lokasi perencanaan pembangunan Arboretum Pengamanan DAS Bolango, tepatnya di 3 lokasi (Gambar 1), yaitu Desa Meranti Kecamatan Tapa Kabupaten Bone Bolango, Desa Dulamayo Selatan Kecamatan Telaga Kabupaten Gorontalo, dan Desa Mongiilo Kecamatan Bolango Ulu Kabupaten Bone Bolango.

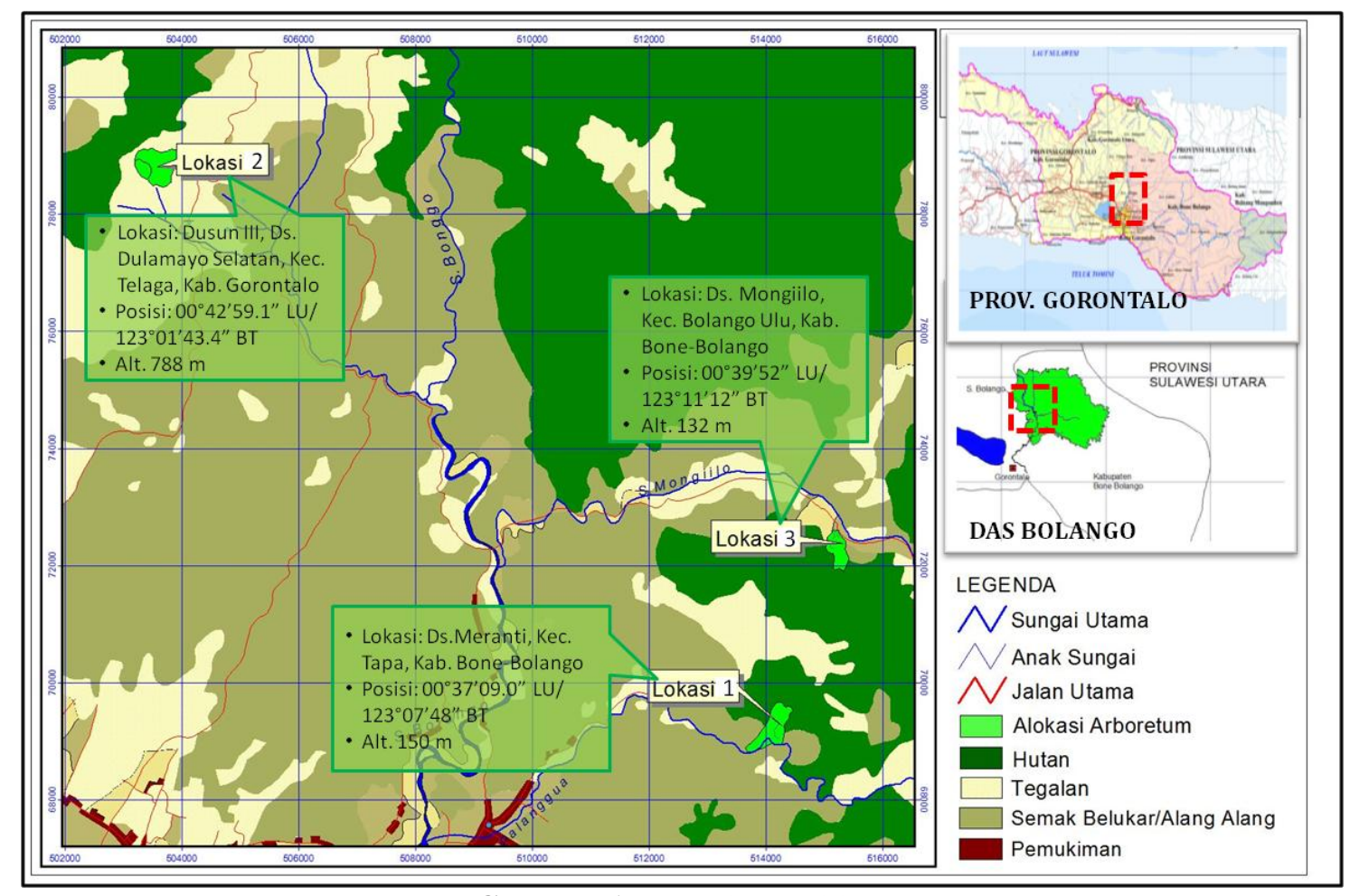

Gambar 1. Lokasi penelitian. 


\section{Bahan dan Alat}

Bahan yang diperlukan terdiri dari kantong plastik, karung goni, tali rafia, alat tulis, kertas label (etiket gantung), kertas $\mathrm{pH}$, tisu gulung, dan bahanbahan untuk analisis kimia tanah. Peralatan yang digunakan antara lain adalah gunting stek untuk memotong sampel daun, cangkul untuk membuat profil tanah, auger handbor untuk mengambil sampel tanah, diameter tape untuk mengukur diameter tanaman, sasak untuk tempat mengepres sampel herbarium, Global Positioning System (GPS) untuk mengetahui koordinat dan ketinggian tempat pengambilan sampel, clinometer untuk mengetahui nilai kemiringan lereng di tempat pengambilan sampel dan kamera digital untuk mendokumentasikan seluruh kegiatan penelitian.

\section{Prosedur}

Penelitian dimulai dengan mengidentifikasi letak sumber mata air utama Sungai Bolango, mencatat titik koordinat, mengukur debit aliran, kondisi fisik dan karakteristik air (pH dan kandungan logam). Pengamatan tanah dilakukan meliputi jenis, profil, $\mathrm{pH}$ dan kondisi fisik tanah. Sampel tanah diambil untuk dianalisis secara kimia di Laboratorium Tanah Balai Penelitian Tanah. Data vegetasi yang diambil meliputi jenis, suku, karakter dan sifatnya, serta pemanfataan tumbuhan oleh masyarakat sekitar. Metode wawancara kepada masyarakat setempat dilakukan untuk mendukung data etnobotani. Herbarium dibuat untuk beberapa jenis tumbuhan yang belum diketahui untuk diidentifikasi lebih lanjut.

Kajian lahan yang dilakukan antara lain analisis tata guna, kelas kemampuan, konsep pengelolaan, dan penentuan vegetasinya. Analisis tata guna lahan meliputi klasifikasi berdasarkan sifat-sifat potensi dan penghambat dalam penggunaannya (Arsyad, 2006; Sitohang dkk., 2013). Penentuan jenis vegetasi dilakukan pada jenis vegetasi penutup tanah (cover crop), jenis tanaman budi daya, dan jenis vegetasi penyusun hutan. Analisis kualitas lahan dilakukan untuk memenuhi persyaratan tumbuh tanaman budi daya. Sementara analisis kesesuaian lahan dilakukan dengan mengkaji jenis tanaman budi daya yang cocok dengan lokasi dan sesuai dengan aspirasi masyarakat sekitar.

\section{HASIL DAN PEMBAHASAN}

\section{Identifikasi Sumber Mata Air Utama}

Pengamanan mata air untuk keseimbangan aliran sungai di suatu DAS sangat terkait dengan kondisi di wilayah hulu, karena sumber-sumber air utama biasanya terletak di kawasan hulu sungai.
Lokasi survei ditentukan di sekitar hulu Sungai Palanggua, Sungai Bolango termasuk Sungai Pupalo, dan Sungai Mongiilo (Gambar 1). Lokasi tersebut dipilih karena mempunyai beberapa mata air dengan potensi kapasitas air yang kontinyu sepanjang tahun sehingga berperan penting bagi kebutuhan masyarakat sekitar.

Berdasarkan hasil pengukuran menggunakan metode pelampung (Harto, 1993; Tjakrawarsa dan Handoko, 2013), diperoleh debit total lokasi 1 sebesar 0,0092 L/detik dengan pH air 7,5-7,9. Lokasi 2 memiliki total debit mata air sebesar 0,0254 $\mathrm{m}^{3}$ /detik dengan $\mathrm{pH}$ air 5-5,8. Lokasi 3 memiliki beberapa mata air utama yang berada pada kelerengan curam. Hasil pengukuran debit air menggunakan current meter di lokasi 3 diperoleh debit rata-rata $0,0515 \mathrm{~m}^{3} /$ detik dengan $\mathrm{pH}$ air 7,57,9. Nilai debit mata air pada lokasi 1 tergolong debit kecil $\left(<0,01 \mathrm{~m}^{3} /\right.$ detik), lokasi 2 debit sedang $(0,01-$ $0,05 \mathrm{~m}^{3} /$ detik), dan lokasi 3 debit agak besar $(0,05-$ $0,1 \mathrm{~m}^{3} /$ detik) (Rahardjo dkk., 2008).

\section{Tipe Penggunaan Lahan}

Berdasarkan hasil survei, terdapat lima tipe penggunaan lahan di lokasi perencanaan, yaitu hutan lindung, hutan produksi alami, perkebunan rakyat, tegalan, dan semak belukar (Gambar 2). Hutan lindung merupakan hutan milik rakyat yang ditetapkan pemerintah daerah sebagai hutan konservasi. Hutan produksi alami merupakan hutan yang diambil manfaatnya berupa hasil hutan kayu dan non kayu oleh masyarakat. Perkebunan rakyat adalah area yang digunakan oleh mayarakat untuk membudidayakan tanaman perkebunan, antara lain kakao, cengkih, kemiri, kayu manis, pisang, dan sebagainya. Tegalan atau ladang merupakan lahan pertanian musiman berupa palawija. Sementara semak belukar pada umumnya ditemukan pada lereng terjal di sekitar sungai, biasanya didominasi jenis nanas hutan (Ananas bracteatus).

\section{Klasifikasi Kemampuan Lahan}

Kelas kemampuan lahan ditentukan oleh faktor pembatas yang paling berat (Arsyad, 2006; Sitohang dkk., 2013), maka berdasarkan hasil analisis ditemukan Lokasi 1 diklasifikasikan ke dalam Kelas IV, Lokasi 2 Kelas VII, dan Lokasi 3 Kelas VI (Tabel 1). Faktor pembatas pada masing-masing lokasi pada umumnya adalah faktor lereng dan erosi. Oleh karena itu untuk mempertahankan atau meningkatkan kemampuan dan potensi lahan diperlukan tindakan konservasi tanah dan air yang tepat. Tindakan konservasi ini berupa cara vegetatif melalui pengaturan vegetasi penutup lahan dan cara mekanik berupa pengolahan tanah, guludan, parit 
pengelak, teras, saluran drainase, dam, dan sebagainya (Sanders, 2004).

Satuan lahan di lokasi 1 mempunyai faktor pembatas terberat adalah lereng yang berada pada peruntukan lahan kelas IV. Tingkat erosi aktual pada umumnya masih bisa ditoleransi. Lahan yang digunakan untuk tanaman budidaya diarahkan untuk kelerengan sedang, sehingga tingkat erosi tanah dapat diklasifikasikan ringan sampai sedang. Lahan ini masih bisa digunakan untuk pertanian, khusus untuk tanaman semusim diperlukan pembuatan teras bangku, saluran bervegetasi, dan dam penghambat. Pada lokasi 2, pembatas paling berat terdapat pada kemiringan lahan (lereng) yang termasuk peruntukan lahan kelas VII.

Lahan ini tidak sesuai untuk pertanian karena selain curam, memiliki tingkat erosi sedang sampai berat. Tingkat erosi dapat dikurangi dengan solum

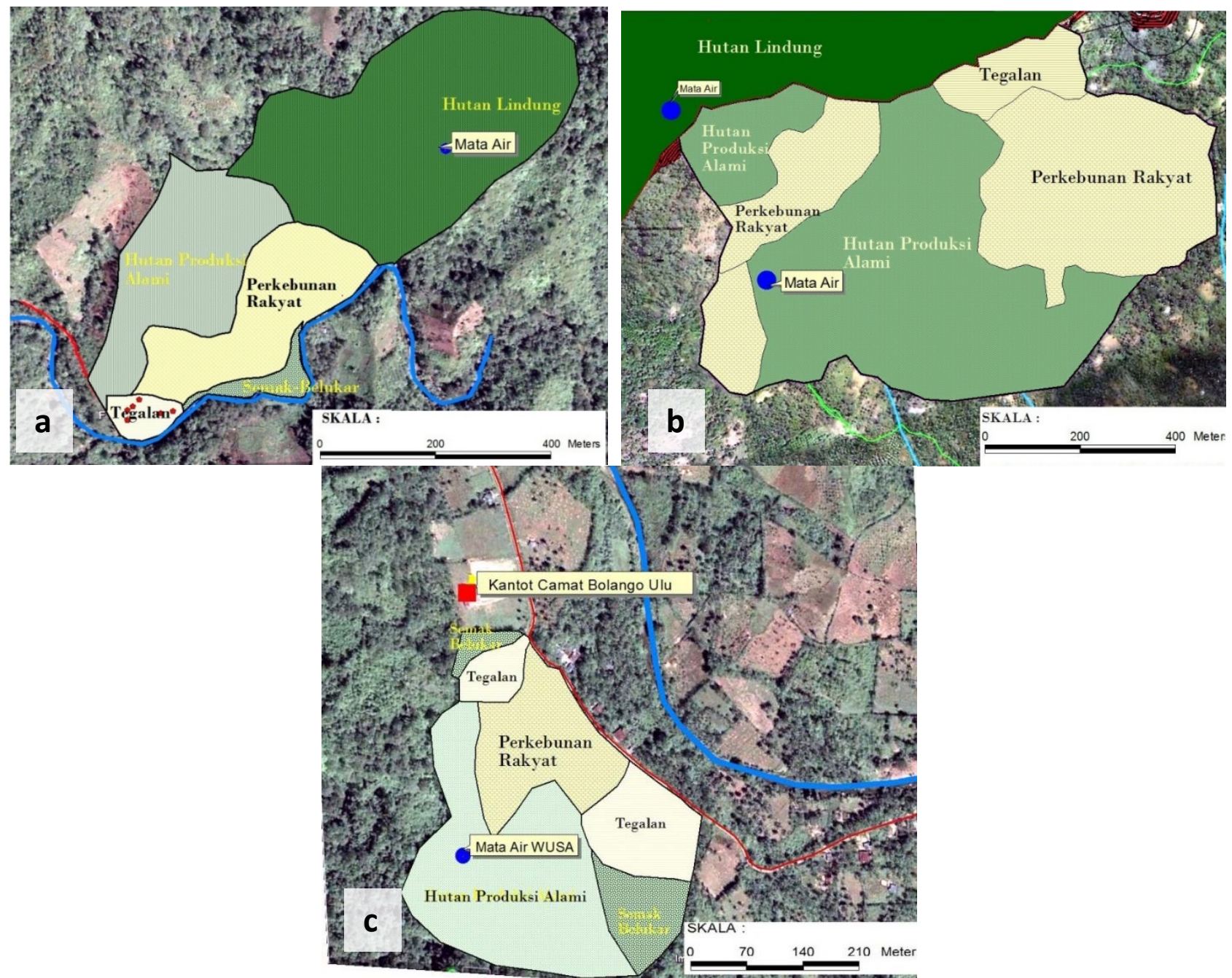

Gambar 2. Tipe penggunaan lahan; (a) lokasi 1 (Desa Meranti); (b) lokasi 2 (Desa Dulamayo Selatan); dan (c) lokasi 3 (Desa Mongiilo).

Tabel 1. Hasil analisis kelas kemampuan lahan Lokasi 1, 2, dan 3.

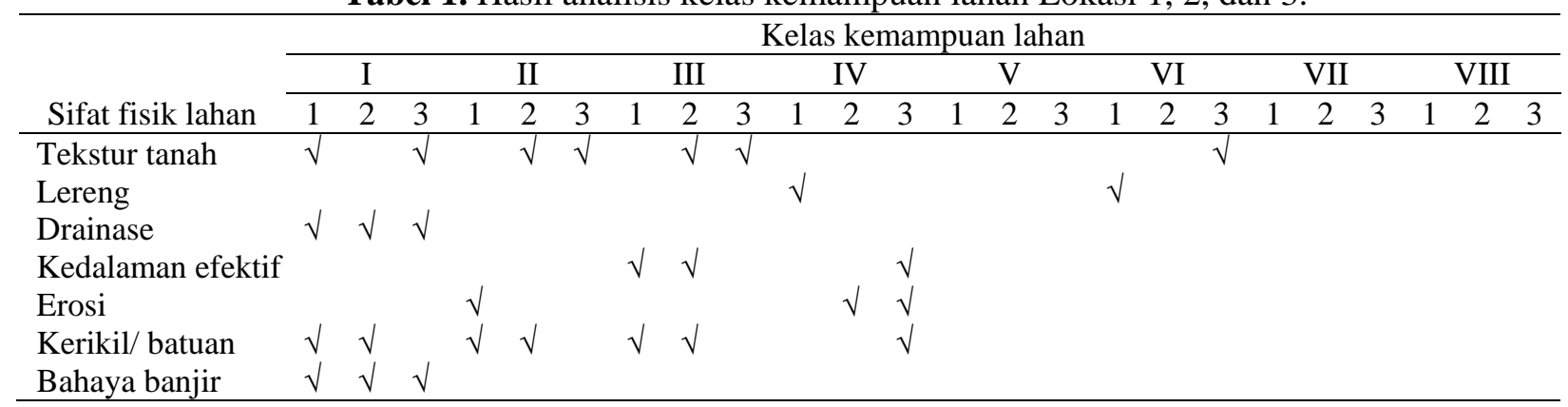

Keterangan: I-VIII: kelas kemampuan lahan; 1: Lokasi 1(Desa Meranti), 2: Lokasi 2 (Desa Dulamayo Selatan), dan 3: Lokasi 3 (Desa Mongiilo). Sumber : Data analisis. 
tanah yang dalam. Pertanian dapat diusahakan dengan syarat pembuatan teras atau sengkedan. Lokasi 3 memiliki faktor pembatas terberat adalah tingkat lereng yang berada pada peruntukan lahan kelas VI. Seperti halnya lokasi 2, kondisi lahan yang curam dengan bahaya erosi yang besar, maka lahan ini tidak bisa digunakan untuk pertanian. Penggunaan efektif untuk padang rumput, hutan produksi, hutan lindung, atau cagar alam.

Sistem pengelolaan yang salah pada daerah yang curam menjadi penyebab utama terjadinya tanah longsor. Kejadian tanah longsor dalam intensitas yang tinggi akan mengganggu kelestarian ekosistem DAS. Salah satu contoh kasus tanah longsor terjadi di DAS Alo yang menjadi faktor terbesar terjadinya pendangkalan Danau Limboto. Kejadian longsor di DAS Alo disebabkan oleh faktor lereng curam, jenis batuan rapuh, curah hujan tinggi, dan sistem pengelolaan lahan yang salah (Lihawa dkk., 2014).

\section{Konsep Pengelolaan}

Pengelolaan lahan yang berkaitan dengan pola tanam harus memperhatikan produktivitasnya. Arboretum didefinisikan sebagai suatu area yang terdiri atas koleksi dari pohon-pohon atau beberapa spesies terpilih untuk tujuan penelitian (Peraturan Menteri Kehutanan Nomor: P.10/Menhut-II/2007 tentang Perbenihan Tanaman Hutan). Oleh karena itu, tipe penggunaan lahan yang sesuai untuk dikembangkan adalah konsep hutan (forestry) dan wanatani (agroforestry). Konsep forestry adalah pembentukan lahan untuk menjadi hutan yang dibiarkan alami dengan penanaman (reboisasi) tanaman kehutanan dan penutup tanah terutama pada lahan dengan kemiringan di atas $45 \%$ atau kelas kemampuan lahan VI, VII dan VIII (Gambar 3a) (Arsyad, 2006). Konsep forestry lainnya adalah dengan aplikasi teras individu dan tanaman penutup tanah rendah (Gambar 3b). Teras individu (satu teras untuk 1 pohon) biasanya dibuat dengan jarak tanam pohon $(1 \mathrm{x} 1 \mathrm{~m})$.

Konsep agroforestry pada prinsipnya adalah menggunakan kembali logika diversitas ekosistem alam ke dalam sistem pertanaman monokultur untuk memperoleh hasil yang lebih stabil, tidak agresif kepada lingkungan tetapi tetap produktif. Iklim mikro yang terbentuk pada pola agroforestry akan membuat kualitas dan kuantitas oksigen dan air lebih stabil (van Noordwijk dkk., 2008). Secara sederhana, konsep ini merupakan sistem tumpangsari berbagai tanaman semusim di antara

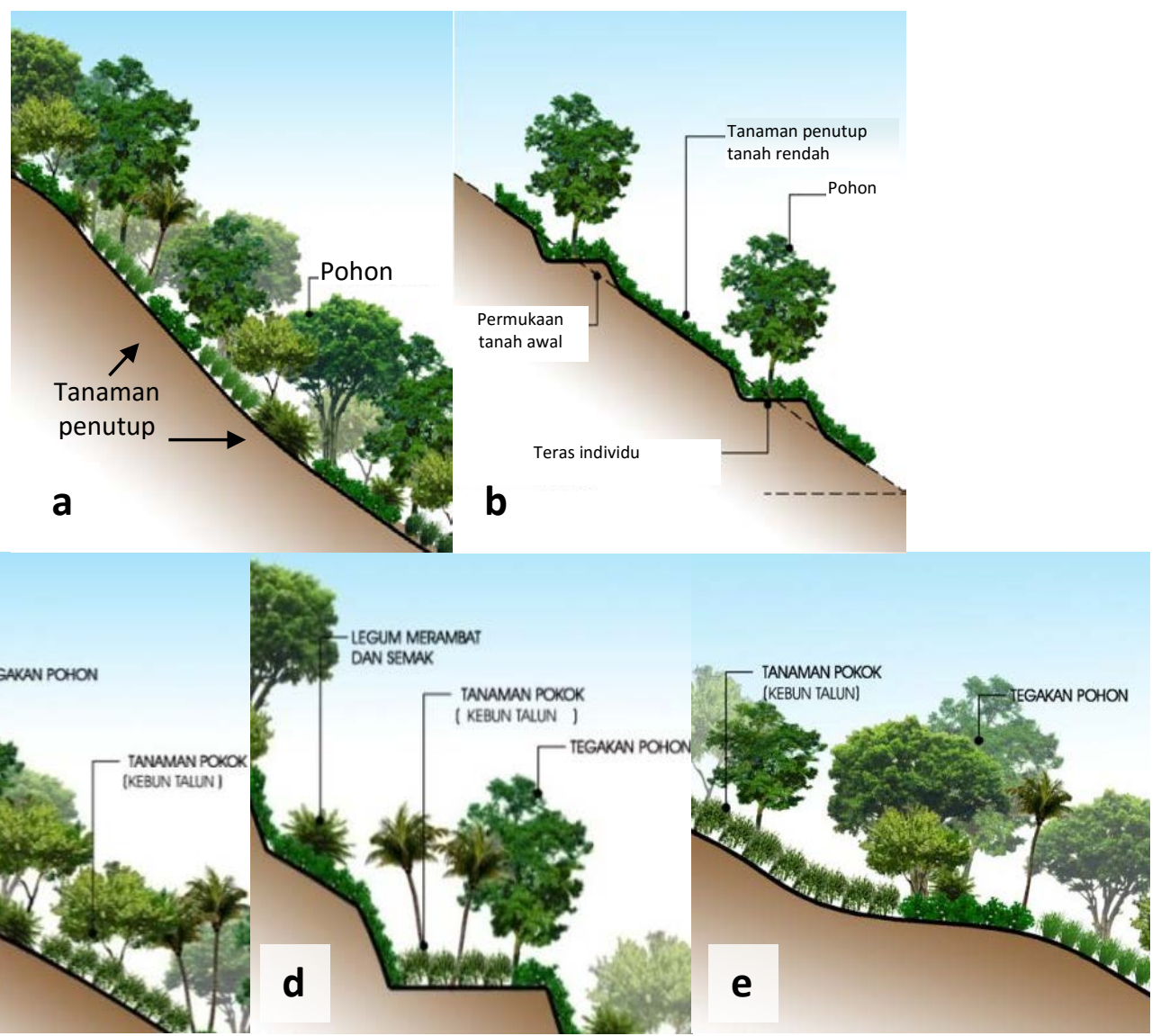

Gambar 3. Konsep Forestry: (a) Hutan campuran; (b) Aplikasi teras individu. Konsep Agroforestry: (c) Kebun talun pada kemiringan 30-45\%; (d) Aplikasi teras pada kebun talun 30-45\%; dan (e) Kebun talun pada kemiringan $<30 \%$ (Sumber Arsyad, 2006 dimodifikasi). 
pepohonan. Konsep agroforestry selalu menjadi pilihan petani karena terdapat peluang untuk mendapatkan beragam produk pertanian (Ethika dkk., 2014).

Sistem kebun talun (mixed tree garden) paling ideal, dimana produk utama dan produk subsistensi rumah tangga dapat dihasilkan secara periodik. Kebun talun dapat diterapkan di ketiga lokasi perencanaan pada kemiringan 30-45\% (Gambar 3c). Tanaman tahunan dapat dipilih sesuai kebutuhan masyarakat dengan tanaman tingkat rendah nanas dan serai wangi, sementara tanaman budidaya tidak disarankan. Teras bangku pada sistem kebun talun untuk kelerengan 30-45\% dilakukan untuk ditanami tanaman semusim, misalnya jagung, kacang, padi gogo, dan ubi jalar. Pada lahan dengan kemiringan di bawah $30 \%$ atau bergelombang dapat diaplikasikan pepohonan dengan tanaman semusim (Gambar 3e).

Konsep pengelolaan DAS secara umum dilakukan untuk mempertahankan dan meningkatkan fungsi ekologis. Keberhasilan pengelolaan DAS akan diperoleh dengan mengintegrasikan berbagai elemen, meliputi; siklus hidrologi, pemahaman konsep ekologi yang benar, dan desain teknik yang menyeluruh (Sangameswaran dan Rowan, 2009). Indikator kunci dari sistem DAS adalah terpeliharanya kestabilan lingkungan, struktur vegetasi, habitat hidupan liar, kualitas air, dan unsur estitika.

\section{Penentuan Jenis Vegetasi}

Terdapat tiga jenis tanaman yang diperlukan untuk menyusun arboretum yang berfungsi konservasi air dan pendukung ekonomi masyarakat sekitar, yaitu tanaman penutup tanah (cover crop), tanaman budi daya, dan tanaman kehutanan (Subagyono dkk., 2003; Arsyad, 2006).

\section{Tanaman penutup tanah (cover crop)}

Tanaman penutup tanah berfungsi sebagai penahan erosi dan sumber bahan organik. Berdasarkan struktur tinggi, tanaman ini terdiri atas tanaman penutup tanah tinggi, sedang, dan rendah (Tabel 2). Penutup tanah tinggi merupakan tanaman utama dengan karakter tanaman keras (kayu), adaptif pada berbagai jenis dan kemiringan tanah. Tanaman penutup tanah sedang merupakan semak berkayu yang berfungsi sebagai tanaman pagar atau tanaman sela, dapat dipanen, dan menjadi sumber bahan organik. Tanaman penutup tanah rendah berupa rumput atau liana yang berfungsi penghambat aliran permukaan, penyaring sedimen, dan sumber bahan organik. Jenis-jenis yang disarankan untuk tanaman rendah adalah kacang-kacangan (Legum Cover Crop/LCC) dan rumput pakan ternak.
Tanaman penutup tanah untuk DAS Bolango yang pernah diterapkan di Sub DAS Langge terdiri atas 2 jenis, yaitu tanaman pangan (food crops) dan sayuran (vegetables) (Anasiru dkk., 2013). Jenis tanaman pangan yang dikembangkan di Sub DAS Langge terdiri atas jagung, padi, dan kacang. Sementara sayuran yang dikembangkan antara lain bawang, cabe, kacang hijau, dan terong. Berdasarkan pertimbangan kondisi lahan, tidak disarankan penggunaan tanaman padi dan bawang di ketiga lokasi perencanaan.

\section{Tanaman budidaya}

Tanaman budidaya memerlukan persyaratan lahan yang meliputi kualitas lahan dan kesesuaian lahan agar dapat diproduksi secara lestari (Sitohang dkk., 2013). Berdasarkan konsep pengelolaan lahan yang telah ditetapkan yakni agroforestry dan forestry, maka analisis kesesuaian lahan dilakukan terhadap tanaman tahunan yang dapat dibudidayakan di ketiga lokasi kajian. Jenis tanaman ditentukan berdasarkan analisa lingkungan tumbuh di ketiga lokasi kajian. Lokasi 1 dan 3 merupakan daerah dataran rendah-sedang dengan elevasi tempat

Tabel 2. Jenis-jenis tanaman penutup tanah (cover crop).

\begin{tabular}{|c|c|}
\hline Jenis tanaman & Nama ilmiah \\
\hline \multicolumn{2}{|c|}{ Tanaman penutup tanah atas: } \\
\hline Sengon laut & Falcataria moluccana \\
\hline Gamal & Gliricidia maculata \\
\hline Dadap & Cajanus cajan \\
\hline Akasia & Acacia albizioides \\
\hline Lamtoro gung & Leucaena leococephala \\
\hline \multicolumn{2}{|c|}{ Tanaman penutup tanah sedang: } \\
\hline Lamtoro merah & Acacia vilosa \\
\hline Petai cina & Leucaena glauca \\
\hline Turi & Sesbania grandiflora \\
\hline Teprosia & Tephrosia candida \\
\hline Orok-orok & $\begin{array}{l}\text { Crotalaria juncea/ Crotalaria } \\
\text { usaramoensis }\end{array}$ \\
\hline Hahapaan & Flemingia congesta \\
\hline \multicolumn{2}{|c|}{ Tanaman penutup tanah rendah (rerumputan): } \\
\hline Jewawut & Setaria viridae \\
\hline Jukut pait & Axonopus compressus \\
\hline Rumput belulang & Eleusine indica \\
\hline Rumput lamuran & Polytria amaura \\
\hline Rumput setaria & Setaria sphacelata \\
\hline Rumput benggala & Panicum maximum \\
\hline Rumput australia & Paspalum dilatatum \\
\hline Rumput gajah & Pennisetum purureum \\
\hline \multicolumn{2}{|c|}{ Tanaman penutup tanah rendah (kacang-kacangan): } \\
\hline Kalopo & Calopogonium caerulium \\
\hline Kacang asu & Calopogonium mucunoides \\
\hline Sentro & Centrosema pubescens \\
\hline Kacang ruji & Pueraria javanica \\
\hline Kudzu & Pueraria thunbergiana \\
\hline
\end{tabular}

Sumber : Hasil analisis. 


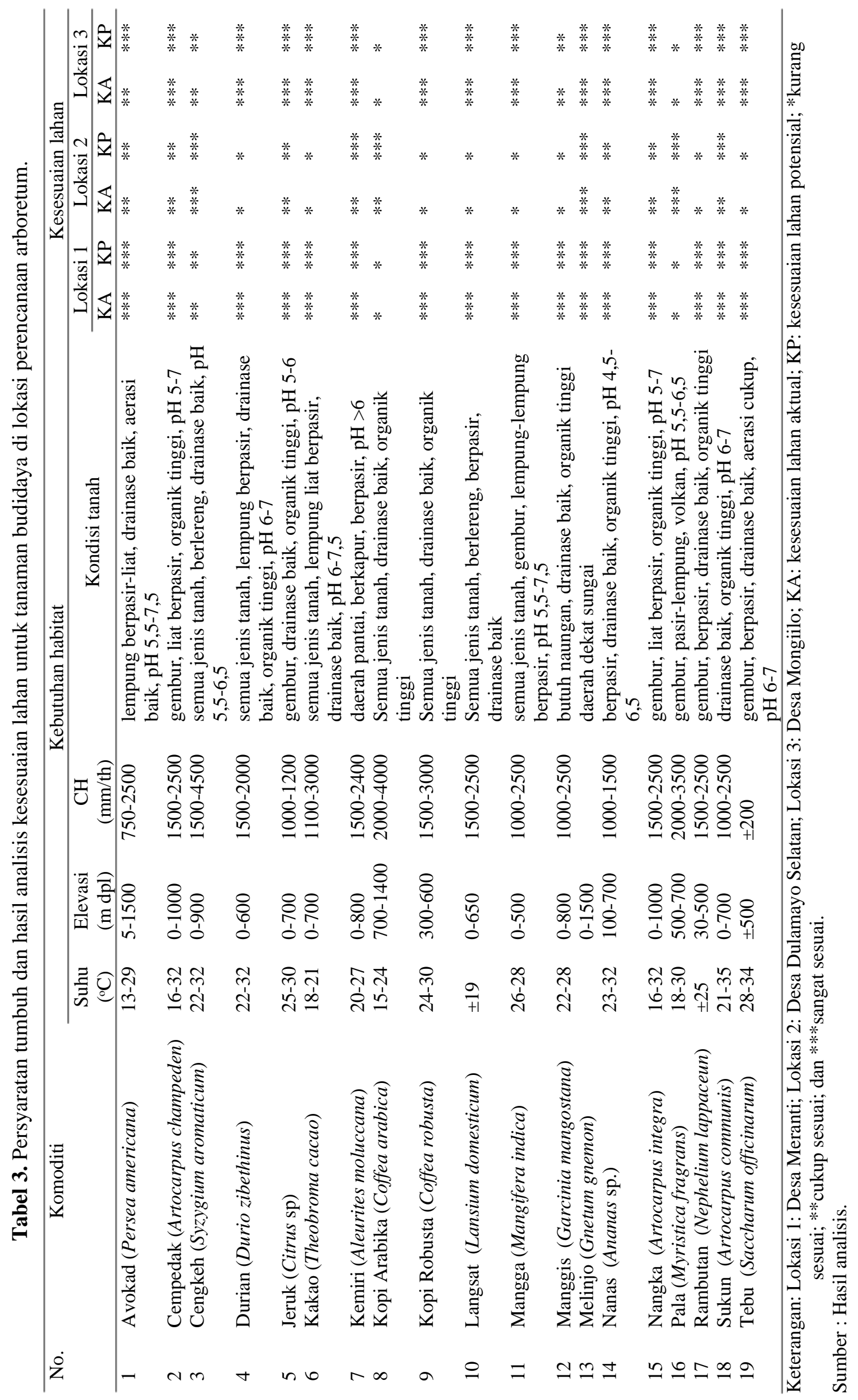




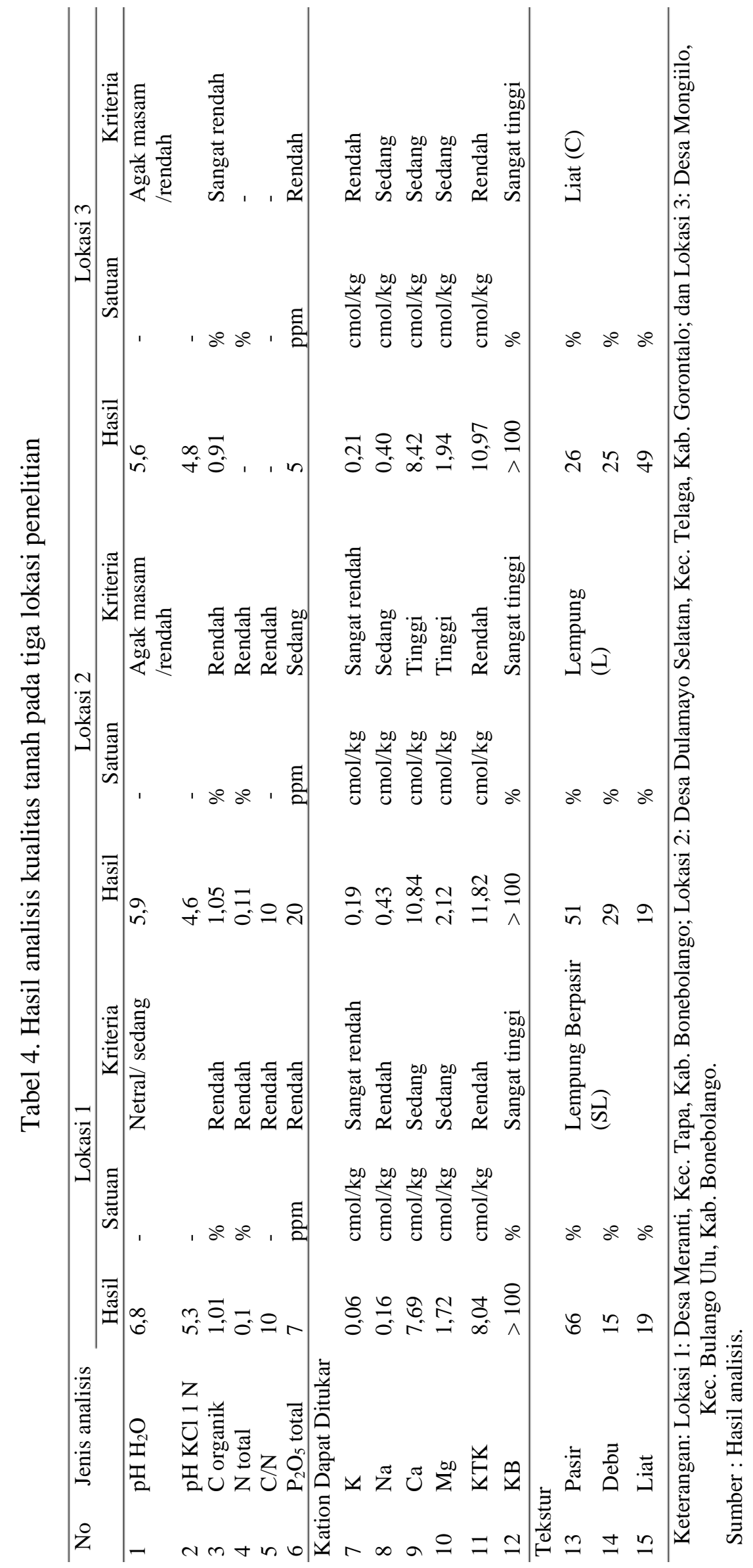


0-700 m dpl, daerah ini memiliki kisaran curah hujan $1500-2500 \mathrm{~mm} / \mathrm{th}$, jenis tanaman yang dapat dibudidayakan di daerah ini adalah avokad, durian, jeruk, kemiri, kopi robusta, langsat, mangga, manggis, melinjo, nanas, nangka, rambutan, sukun, dan tebu. Lokasi 2 dapat digolongkan kepada daerah dataran tinggi dengan elevasi tempat 700-1500 m dpl, daerah ini memiliki kisaran curah hujan rata-rata 2500-3500 mm/th, jenis tanaman yang dapat diusahakan di daerah ini adalah cengkeh, kopi arabika, melinjo, dan pala. Analisis kesesuaian lahan dilakukan terhadap tanaman dilakukan dengan membandingkan kualitas lahan dengan persyaratan tumbuh tanaman budidaya (Tabel 3).

Tabel 5. Jenis-jenis pohon potensial untuk konservasi air dan sumber pakan satwa.

\begin{tabular}{|c|c|c|c|}
\hline No & Nama ilmiah & Suku & Manfaat \\
\hline 1. & Abizia lebeck (L.) Benth & Mimosaceae & Kayu untuk bangunan \\
\hline 2. & Anthocepalus chinensis (Lamk.) Rich. Ex Walp. & Rubiaceae & Kayu untuk bangunan \\
\hline 3. & Antidesma bunius (L.) Spreng & Euphorbiaceae & Kayu untuk kerjinan, buah dimakan \\
\hline 4. & Areca cathecu L. & Arecaceae & Kayu untuk bangunan, akar untuk obat \\
\hline 5. & Artocarpus communis J.R. \& G. Forst. & Moraceae & Buah dan biji dapat dimakan \\
\hline 6. & Artocarpus altilis (Park.) Fosberg & Moraceae & Buah dan biji dapat dimakan \\
\hline 7. & Artocarpus heterophylla Lkm. & Moraceae & $\begin{array}{l}\text { Kayu untuk bangunan, buah dimakan satwa } \\
\text { (burung dan tupai) }\end{array}$ \\
\hline 8. & Dendrocalamus asper (Schult.) Backer ex Heyne & Poaceae & $\begin{array}{l}\text { Kayu untuk bangunan dan kerajinan, rebung } \\
\text { dimakan }\end{array}$ \\
\hline 9. & Diospyros macrophylla $\mathrm{Bl}$. & Ebenaceae & $\begin{array}{l}\text { Kayu untuk bangunan dan kerajinan, buah } \\
\text { dimakan satwa (burung, tupai, kelelawar) }\end{array}$ \\
\hline 10. & Dysoxylum gaudichadianum (A. Juss.) Miq. & Meliaceae & Kayu untuk bangunan \\
\hline 11. & Ficus ampelas Burm.f. & Moraceae & Kayu bakar, daun untuk ampelas \\
\hline 12. & Ficus callophylla Blume & Moraceae & Kayu untuk bangunan \\
\hline 13. & Ficus callosa Willd. & Moraceae & Peneduh \\
\hline 14. & Ficus racemosa L. & Moraceae & Buah dapat dimakan \\
\hline 15. & Ficus septica Burm.f. & Moraceae & Kayu untuk perkakas dalam air laut \\
\hline 16. & Garuga floribunda Decne & Burseraceae & Kayu untuk bangunan \\
\hline 17. & Gluta renghas L. & Anacardiaceae & Kayu untuk bangunan \\
\hline 18. & Lagerstroemia speciosa (L.) Pers. & Lytheraceae & Kayu untuk bangunan, tanaman hias \\
\hline 19. & Pterocymbium javanicum R.Br. & Sterculiaceae & Kayu untuk bangunan \\
\hline 20. & Schleicera oleosa (Lour.) Oken & Sapindaceae & Kayu untuk bangunan, getah untuk cat \\
\hline 21. & Sterculia coccinea Jack. & Sterculiaceae & Kayu untuk bangunan, buah untuk pewarna \\
\hline 22. & Sterblus asper Lour. & Moraceae & Kayu untuk kerajinan, tanaman hias \\
\hline 23. & Terminalia microcarpa Decne & Combretaceae & Kayu untuk bangunan \\
\hline
\end{tabular}

Tabel 6. Jenis-jenis pohon langka yang tersebar alami di Sulawesi.

\begin{tabular}{llcc}
\hline No & \multicolumn{1}{c}{ Nama jenis } & Suku & Status kelangkaan (IUCN 2011) \\
\hline 1 & Aglaia elliptica Blume & Meliaceae & LR/lc \\
2 & Aglaia lawii (Wight) Saldanha ex Ramamoorthy & Meliaceae & LR/lc \\
3 & Aglaia smithii Koord. & Meliaceae & LR/lc \\
4 & Alstonia scholaris (L.) R. Br. & Apocynaceae & LR/lc \\
5 & Bhesa robusta (Roxb.) Ding Hou & Celastraceae & LR/lc \\
6 & Caryota no Becc. & Arecaceae & CR \\
7 & Cassine koordersii Kosterm. & Celastraceae & LR/lc \\
8 & Dacrycarpus imbricatus (Blume) de Laub. & Podocarpaceae & VU \\
9 & Diospyros celebica Bakh. & Ebenaceae & EN \\
10 & Heritiera globosa Kosterm. & Sterculiaceae & LR/lc \\
11 & Homalium foetidum (Roxb.) Benth. & Flacourtiaceae & LR/lc \\
12 & Horsfieldia sylvestris (Houtt.) Warb. & Myristicaceae & VU \\
13 & Intsia bijuga (Colebr.) Kuntze & Caesalpiniaceae & VU \\
14 & Mangifera pedicellata Kosterm. & Anacardiaceae & LR/lc \\
15 & Myristica iners Blume & Myristicaceae & LC \\
16 & Nypa fruticans Wurmb & Arecaceae & LR/nt \\
17 & Orania sylvicola (Griff.) H.E. Moore & Arecaceae & LR/lc \\
18 & Prunus javanica (Teijsm. \& Binn.) Miq. & Rosaceae & VU \\
19 & Pterocarpus indicus Willd. & Papilionaceae & \\
\hline
\end{tabular}

Keterangan: CR: critically endangered/kritis, EN: endangered/terancam, VU: vulnerable/rentan, LR: low risk/beresiko rendah, NT: near threatened/hampir terancam, LC: least concern/sedikit mengkhawatirkan. (Sumber: Anonim, 2010) 
Kualitas lahan yang terkait dengan penilaian terhadap sifat fisik-kimia dianalisis di laboratorium. Hasil analisis laboratorium (Tabel 4) menyebutkan bahwa lokasi 1 memiliki tingkat kecukupan hara tanah yang rendah sampai sedang. Drainase dan aerasi tanah cukup menunjang sebagai media perakaran. Tekstur tanah berpasir dengan kemiringan agak curam sampai curam menyebabkan ancaman erosi yang sedang sampai berat. Hambatan lain adalah unsur toksik dan batuan singkapan yang tidak ada. Lokasi 2 memiliki kecukupan hara tanah rendah, namun drainase dan aerasi tanah dapat menunjang perakaran. Untuk lokasi 3 memiliki kecukupan hara sangat rendah sampai rendah tetapi media perakarannya cukup baik.

Berdasarkan kualitas tanah, ketiga lokasi memiliki media perakaran yang cukup baik untuk tanaman budi daya. Permasalahan yang ada adalah tingkat kecukupan unsur hara yang rendah dan tingkat bahaya erosi. Oleh karena itu perlu dilakukan pembuatan teras dan penerapan pola tanam konservasi. Satuan lahan yang tidak dapat diperbaiki tidak akan dilakukan perubahan kelas kesesuaiannya. Satuan lahan yang dapat diperbaiki dapat berubah menjadi satu atau dua tingkat lebih baik.

Hasil analisis kesesuaian lahan disajikan dalan penilaian kelas kesesuaian lahan aktual (KA) dan potensial (KP) (Tabel 3). Kesesuaian lahan aktual merupakan kesesuaian berdasarkan kualitas tanah eksisting, sedangkan kesesuaian lahan potensial merupakan kelas yang dapat dicapai setelah dilakukan usaha-usaha perbaikan terhadap faktorfaktor penghambat yang ada. Kesesuaian lahan potensial dapat dijadikan dasar pemilihan komoditi yang akan dikembangkan.

Secara umum, semua jenis tanaman budi daya tersebut sesuai untuk ketiga lokasi arboretum. Faktor penghambat yang berupa mininmya unsur hara tanah dapat diatasi dengan pemberian pupuk organik berupa kompos dan pupuk kandang. Bahaya erosi dapat dikurangi dengan penerapan tindakan konservasi tanah dan air diantaranya dengan pembuatan teras. Tindakan konservasi tersebut harus memperhatikan aspek ekonomi, dimana petani harus mendapatkan keuntungan lebih. Pembuatan teras menjadi kebutuhan penting karena lahan-lahan yang miring berpengaruh besar terhadap keagresifan limpasan karena kemiringan lahan turut mengendalikan volume, kecepatan, daya rusak, dan daya angkut limpasan (Hendrawan, 2004). Bahkan, jika derajat meningkat dua kali maka laju erosi tanahnya akan meningkat sebesar 2,8 kali (Sitohang dkk., 2013).

\section{Pohon penyusun hutan}

Komposisi jenis-jenis pohon harus diselaraskan dengan tujuan arboretum sehingga pola penanamannya dapat dikombinasikan secara acak, organik, dan geometrik. Jenis-jenis vegetasi penyusun hutan arboretum harus berperan dalam konservasi air, pelestarian jenis langka, perlindungan jenis lokal, dan penyedia habitat satwa (Tabel 5). Jenis-jenis pohon yang mampu meningkatkan kualitas dan kuantitas air misalnya Ficus sp (beringin), Artocarpus altilis (sukun), dan Syzygium polyantum (salam) (Soejono, 2011). Tanaman pertanian dan wanatani (agroforestry) juga berperan penting dalam menjaga sistem tata air (van Noordwijk dkk., 2008).

Konsep arboretum yang menyerupai ekosistem alam akan menarik berbagai jenis satwa liar untuk hadir dan berkembang biak. Berbagai jenis buah dan biji akan menjadi sumber pakan bagi burung-burung dan mamalia. Pohon-pohon besar dengan tajuk lebat merupakan tempat berlindung yang nyaman bagi berbagai jenis burung (Purnomo, 2012). Keseluruhan jenis satwa liar tersebut merupakan konsekuensi yang harus dipelihara dan dijaga kelestariannya sejalan dengan peran dan fungsi arboretum.

Pulau Sulawesi merupakan bagian dari kawasan Wallacea yang menjadi penyumbang plasma nutfah tumbuhan penting di Indonesia. Jenisjenis langka terutama jenis asli Sulawesi menjadi bagian penting dalam konsep tata hijau arboretum (Tabel 6). Kesesuaian dengan iklim setempat dan ketahanan hidup yang tinggi merupakan salah satu nilai lebih untuk mengangkat jenis tumbuhan lokal.

\section{KESIMPULAN}

Ketiga lokasi perencanaan arboretum memiliki sumber mata air penting bagi masyarakat sekitarnya. Nilai debit mata air pada lokasi 1 tergolong debit kecil, lokasi 2 debit sedang, dan lokasi 3 debit agak besar. Berdasarkan kualitas tanah, ketiga lokasi memiliki media perakaran yang cukup baik untuk tanaman budi daya. Secara umum, semua jenis tanaman budi daya sesuai untuk ketiga lokasi arboretum. Permasalahan yang ada adalah tingkat kecukupan unsur hara yang rendah dan tingkat bahaya erosi. Oleh karena itu perlu dilakukan pembuatan teras dan penerapan pola tanam konservasi yang mengaplikasikan tanaman penutup tanah (cover crop), tanaman budi daya, dan pohon penyusun hutan. Faktor penghambat yang berupa minimnya unsur hara tanah dapat diatasi dengan pemberian pupuk organik berupa kompos dan pupuk kandang. 


\section{DAFTAR PUSTAKA}

Anasiru, R.H., Rayes, M.L., Setiawan, B., dan Sormarno, 2013. An Agro-ecological Approach for Sustainable Farming in Langge Sub-watershed, Bolango Watershed, Gorontalo, Indonesia. Journal of Environment and Earth Science, 3(5):1-11.

Anonim, 2007. Watershed Services: The Important Link Between Forests and Water. The U.S. Department of Agriculture (USDA). Washington D.C.

Anonim, 2010. Katalog Koleksi Kebun Raya Bogor. PKT Kebun Raya Bogor - LIPI. Bogor.

Anonim, 2011 . Bone Bolango dalam Angka Tahun 2011. Badan Pusat Statistik Kabupaten Bone Bolango. Bone Bolango.

Anonim, 2011 . Tapa dalam Angka 2011. Badan Pusat Statistik Kabupaten Bone Bolango. Bone Bolango.

Arsyad, S., 2006. Konservasi Tanah dan Air. IPB Press. Bogor.

Ethika, D., Purwanto, R.H., Senawi, dan Masyhuri. 2014. Peranan Petani Terhadap Strategi Pembangunan Hutan Rakyat di Bagian Hulu Sub DAS Logawa di Kabupaten Banyumas, Jawa Tengah. Jurnal Manusia dan Lingkungan, 21(3):377-385.

Harto, B.S., 1993. Analisis Hidrologi. PT. Gramedia Pustaka Utama. Jakarta.

Hendrawan, H., 2004. Aplikasi Sistem Informasi Geografi (SIG) untuk Pendugaan Erosi dengan Pendekatan USLE (Universal Soil Loss Equation) di Sub-DAS Cimuntur Ciamis. Skripsi. Jurusan Teknologi Pertanian. Institut Pertanian Bogor. Bogor.

Irianto, G. dan Rejekiningrum, P., 2008. Efisiensi Pemanfaatan Sumber Daya Air: Suatu Tinjauan Dari Sisi Agroklimat dan Hidrologi. Dalam S. Arsyad dan E. Rustiandi (Ed.). Penyelamatan Tanah, Air, dan Lingkungan. Crestpent Press dan Yayasan Obor Indonesia.

Laird, S.G., Ford, C.R., Laseter, S.H., dan Vose, J.M., 2011. Long-term Forest Management and Climate Effects on Streamflow. The Fourth Interagency Conference on Research in the Watersheds, 26-30 September 2014. Fairbanks.

Lihawa, F., Patuti, I.M., dan Nurfaika. 2014. Sebaran Aspek Keruangan Tipe Longsoran di
Daerah Aliran Sungai Alo Provinsi Gorontalo. Jurnal Manusia dan Lingkungan, 21(3):277285.

Purnomo, D.W., 2012. Desain Koridor Vegetasi Untuk Mendukung Nilai Konservasi di Kawasan Perkebunan Kelapa Sawit. Jurnal Bumi Lestari, 12(2):268-282.

Rahardjo, N., Purnama, S., dan Sulaswono, B., 2008. Pemetaan Potensi Mata Air di Pulau Bali. Jurnal Rekayasa Lingkungan, 4(2):71-78.

Sanders, D., 2004. Soil Conservation, in Land Use, Land Cover and Soil Sciences, [Ed. Willy H. Verheye], in Encyclopedia of Life Support Systems (EOLSS), Developed under the Auspices of the UNESCO, Eolss Publishers, Oxford .

Sangameswaran, S. dan Rowan, J. 2009. Sustainable Watershed Planning and Design Using Bioengineered Solutions. Watershed Update, 7(2):1-6.

Sitohang, J.L., Sitorus, B., dan Sembiring, M., 2013. Evaluasi Kemampuan Lahan Desa Sihiong, Sinar Sabungan dan Lumban Lobu Kabupaten Toba Samosir. Jurnal Online Agroekoteknologi, 1(3):8442-852.

Soejono, 2011. Jenis Pohon di Sekitar Mata Air. UPT Balai Konservasi Tumbuhan Kebun Raya Purwodadi-LIPI, Pasuruan.

Subagyono, K., Marwanto, S., dan Kurnia, U., 2003. Teknik Konservasi Tanah Secara Vegetatif. Balai Penelitian Tanah, Pusat Penelitian dan Pengembangan Tanah dan Agroklimat, Badan Penelitian dan Pengembangan Pertanian, Departemen Pertanian. Jakarta.

Tjakrawarsa, G. dan Handoko, C., 2013. Kajian Teknik Perlindungan Mata Air di Pulau Lombok: Studi Kasus di KHDTK Rarung. Indonesian Forest Rehabilitation Journal, 1(1):1-15.

Tresnadi, H. 2008. Pengelolaan DAS dengan Pendekatan Ekosistem. Studi Kasus Analisis Debit Sungai Bone dan Bolango di Kabupaten Bone Bolango, Propinsi Gorontalo. Jurnal Hidrosfer Indonesia, 3(2):95-104.

van Noordwijk, M., Hairiah, H., Suhardi, Sabarnurdin, S., Soedjalmo, R., Sarma, M., dan Suntoro, 2008. Bunga Rampai: Pendidikan Agroforestri Sebagai Strategi Menghadapi Perubahan Iklim Global. World Agroforestry Centre (ICRAF). Bogor. 